\title{
HERMENEUTIKA AL-QUR'AN TENTANG PLURALISME AGAMA PERSPEKTIF FARID ESACK
}

\author{
Akhmad Ali Said \\ 4ssaid.aly@gmail.com \\ Dosen Ilmu Tasawuf IAI Pangeran Diponegoro Nganjuk
}

\section{Abstrak}

Al-Qur'an memiliki muatan universal (sātị̧ li kulli zamān wa makān) sehingga memberikan spirit berupa nilai kebebasan (alburriyab), nilai-nilai bumanistic, nilai keadilan (al-'adālab), kesetaraan (al-musāwab), dan hak asasi manusia (buqūq al-insān). Nilai-nilai universal yang berorientasi pada spirit al-Qur'an inilah yang menjadi konsentrasi Farid Esack. Dia adalah seorang pemikir dari Afrika Selatan. Lewat karya dan keterlibatannya dalam gerakan praksis, Esack mendobrak klaim kebenaran eksklusif agama dan mengkonstruksi konsep pluralisme agama untuk membebaskan masyarakat Afrika Selatan dari belenggu kolonialisme rezim Apartheid. Dalam hermeneutiknya, Esack menempatkan teks (al-Qur'an), konteks Afrika Selatan dan penafsir berada pada posisi lingkaran hermeneutik. Pada posisinya sebagai pembaca sekaligus sebagai pengarang Esack menekankan adanya sebuah pembacaan yang kritis dan membebaskan dalam menafsirkan teks ke dalam konteks. Hermeneutika yang ditawarkan Farid Esack sebagai metode penafsiran al-Qur'an untuk membangun landasan teologis tentang konsep pluralisme agama. Dalam pandangan Esack, ada kemungkinan untuk hidup dalam kepercayaan penuh terhadap al-Qur'an dan konteks kehidupan sekarang bersama-sama kepercayaan-kepercayaan lain dan bekerjasama untuk membangun masyarakat yang lebih manusiawi. Esack mengembangkan gagasan hermeneutika al-Qur'an sebagai kontribusi bagi pengembangan pluralisme agama dalam Islam; menguji cara al-Qur'an mendefinisikan diri (muslim) dan orang lain (non-muslim) dengan tujuan untuk menciptakan ruang bagi kebenaran dan keadilan orang lain dalam teologi pluralisme 
untuk pembebasan; dan menggali hubungan antara eksklusivisme keagamaan dalam bentuk konservatisme politik (yang mendukung Apartheid) di satu sisi, dan inklusivisme keagamaan dan satu bentuk politik progresif (yang mendukung perjuangan pembebasan) di sisi lain, serta memberi dukungan rasional yang bersifat qur'ani, untuk membebaskan masyarakat Afrika Selatan dari belenggu rezim Apartheid.

Kata Kunci: Hermeneutika, Pluralisme Agama, Farid Esack

\section{A. Latar Belakang}

Al-Qur'an bagi kaum Muslimin adalah mukjizat yang kekal dan kebenarannya itu mutlak sesuai dengan konteks waktu dan tempat (sălị̧ li kulli zamān wa makān). Al-Qur'an merupakan kalam Allah yang diturunkan kepada Nabi Muhammad saw. melalui perantara malaikat Jibril selama kurang lebih dua puluh tiga tahun, yang tertulis pada mushaf yang ditranmisikan secara mutawatir, menjadi petunjuk bagi manusia dan membacanya sebagai ibadah. Kitab suci al-Qur'an sebagai petunjuk bagi manusia untuk keluar dari suasana yang gelap menuju yang terang, serta membimbing mereka ke jalan yang lurus.

Kehadiran al-Qur'an di tengah umat Islam khususnya telah melahirkan pusat pusaran wacana keislaman yang tak pernah berhenti, bahwa teks al-Qur'an merupakan "sosok pribadi" yang mandiri, otonom, dan secara obyektif memiliki kebenaran yang bisa dipahami secara rasional. Al-Qur'an adalah kitab suci yang menurut Komaruddin Hidayat memiliki dua karakter; yaitu karakter sentrifugal dan karakter sentripetal. ${ }^{2}$ Karakter sentrifugal adalah karakter al-Qur'an yang membuka ruang penafsiran bagi siapapun yang membacanya. Al-Qur'an mempunyai daya dorong yang kuat bagi umat Islam untuk melakukan penafsiran dan pengembangan makna atas ayat-ayatnya.

${ }^{1}$ Mannā' Khāil al-Qattān, Mabāhith $\bar{f}$ Ulum al-Qur'ān. cet. 11, Kairo: Maktabah Wahbah: 2000, 1.

${ }^{2}$ Komaruddin Hidayat,Menafsirkan Kehendak Tuhan. Cet. 2, Jakarta: Teraju, 2004, 17. 
Sementara karakter sentripetal, al-Qur'an selalu menjadi ruang kembali dari setiap penafsiran. Maksudnya, meskipun seluruh wacana keislaman yang berlangsung belasan abad dan telah melahirkan sekian banyak tafsir dan persoalan hidup, namun upaya untuk selalu merujuk pada al-Qur'an juga sangat kuat. ${ }^{3} \mathrm{Hal}$ itu seperti halnya yang dikutip oleh M. Quraish Shihab dari Abdullah Darras, "Ayat-ayat al-Qur'an bagaikan intan. Setiap sudutnya memancarkan cahaya yang berbeda dengan apa yang terpancar dari sudut lainnya. Dan tidak mustahil jika kita mempersilahkan orang lain memandangnya dari sudut lainnya, maka dia akan melihat banyak hal dibanding apa yang kita lihat".

Tafsir al-Qur'an sebagai sebuah bagian dari tradisi dan peradaban Islam. Proses penafsiran terhadap al-Qur'an merupakan sebuah hasil refleksi dan pengalaman personal hasil interaksi dengan al-Qur'an yang tidak mengenal finalitas. Dalam hal ini, tafsir merupakan sebuah kerja hermeneutik, yaitu teori yang mengoperasikan pemahaman dalam kaitannya dengan penafsiran sebuah teks. ${ }^{5}$

Para ulama dan cendekiawan Muslim ketika berhadapan dengan ayat-ayat al-Qur'an dalam rangka memetik kandungannya melalui penafsiran yang mereka lakukan, tentu tidak dapat melepaskan diri dari prinsip yang melatar-belakanginya. Dalam teori hermeneutik hal itu sering disebut dengan istilah prior text atau alafaq al-musbiqab (horison atau teks yang mendahului), di saat penafsir memahami al-Qur'an, baik ia menyadari maupun tidak menyadarinya. ${ }^{6}$ Proses penerjemahan, penafsiran dan pemahaman atas sebuah teks selalu mengasumsikan adanya tiga subyek yang terlibat, yaitu: dunia pengarang, dunia teks, dan dunia pembaca.

${ }^{3}$ Ibid, 18.

${ }^{4}$ M. Quraish Shihab, Tafsir al-Misbah: Pesan, Kesan dan Keserasian al-Qur'an. Volume I, Jakarta: Lentera Hati, 2000, XV.

${ }_{5}^{5}$ Zuhairi Misrawi, Al-Qur'an Kitab Toleransi. Jakarta: Pustaka Oasis, 2010, 104.

${ }^{6}$ Abdul Mustaqim, Dinamika Sejarah Tafsir Al-Qur'an.Yogyakarta: Adab Press, 2012, 20. ${ }^{7}$ Dengan memperhatikan ketiga pokok tersebut, maka metode hermeneutika tidak mungkin mengabaikan hubungan dialektik antara teks, mufassir dan realitas dalam 
Spiritualis, vol. 6, no. 1, Maret 2020| 4

Persoalan menjadi rumit ketika jarak waktu, tempat dan kebudayaan antara pembaca dan dunia yang lain, yaitu pengarang dan teks, demikian jauh. Al-Qur'an sebagai teks keagaaman yang lahir sekian abad yang lalu di dunia Timur Tengah, ketika hadir di tengah masyarakat Indonesia kontemporer tentu saja merupakan sesuatu yang asing. Persoalan keterasingan inilah yang menjadi persoalan hermeneutik sebagai sebuah teori interpretasi. Peran hermeneutik ialah bagaimana menafsirkan sebuah teks klasik atau teks yang asing sama sekali agar menjadi milik kita yang hidup di zaman dan tempat serta suasana kultural yang berbeda. ${ }^{8}$

Dalam tradisi sarjana Muslim kontemporer, sebenarnya telah banyak pemikir yang menggunakan hermeneutika dalam studi al-Qur'an, semisal Hasan Hanafi, Fazlur Rahman, Mohammed Arkoun, Farid Esack dan sebagainya. Hassan Hanafi mempublikasikan tiga karya yang bercorak hermeneutik; yang pertama berkaitan dengan upaya rekonstruksi ilmu ushul fiqih, yang kedua berkaitan dengan hermeneutika fenomenologis dalam menafsirkan fenomena keagamaan dan keberagamaan, dan yang ketiga berhubungan dengan kajian kritis terhadap hermeneutika eksistensial dalam kerangka penafsiran Perjanjian Baru. Mohammed Arkoun dari Aljazair mencetuskan idenya mengenai "cara baca" semiotik terhadap al-Qur'an, dan Fazlur Rahman merumuskan metode hermeneutika yang sistematik terhadap alQur'an dan dikenal sebagai "double movement".

Paradigma ${ }^{9}$ tafsir para penafsir Muslim kontemporer yang cenderung bernuansa hermeneutic, lebih menekankan pada aspek

menentukan makna. Untuk kasus al-Qur'an, yang merupakan sebuah hubungan komunikatif antara pengirim dengan penerima yang tercipta melalui bantuan suatu kode atau sistem bahasa. Karena dalam hal ini, Pengirim atau dunia pengarang alQu'ran tidak bisa menjadi subyek penelitian ilmiah, studi terhadap teks harus didasarkan pada premis mengenai realitas yang dapat diverifikasi yakni berupa budaya umat yang dituju oleh teks sebagaimana penerima pertamanya, yaitu: Rasulullah Saw. Farid Esack, The Qur'an; a Users Guide. Oxford: OneWorld Publication, 2005, 142-143. ${ }^{8}$ Komaruddin Hidayat, Menafsirkan Kebendak Tuhan..., 20.

'Secara sederhana paradigma adalah cara memandang. Secara ilmiah paradigma adalah "a constellation of beliefs, values, and techniques shared by members of a given scientific community". 
epistemologis-metodologis dalam mengkaji al-Qur'an untuk menghasilkan pembacaan yang produktif dan mengungkapkan makna kontekstual yang berorientasi pada semangat al-Qur'an yang bernilai universal (sāith li kulli zamān wa makān). Nilai universal yang dimaksud adalah nilai kebebasan (al-hurriyah), nilai-nilai humanistic, nilai keadilan (al-'adālab), kesetaraan (al-musāwab), dan hak asasi manusia (ḅuqüq al-insān). ${ }^{10}$

Nilai-nilai universal yang berorientasi pada spirit al-Qur'an inilah yang menjadi konsentrasi Farid Esack. Ia adalah seorang pemikir dari Afrika Selatan yang tengah banyak mendapat perhatian internasional lewat karya dan keterlibatannya dalam gerakan praksis. Dia berusaha mendobrak klaim kebenaran eksklusif agama untuk kemudian menggantinya dengan gagasangagasan pluralis dan membebaskan. Farid Esack, dengan pengalaman pribadi di negaranya sendiri dan di Pakistan, melihat kontradiksi mendalam antara idealitas kitab suci dengan praktik keberagamaan penganutnya.

Tulisan ini akan mendiskusikan berbagai hal tentang hermeneutika yang ditawarkan Farid Esack sebagai metode penafsiran al-Qur'an untuk membangun landasan teologis tentang konsep pluralisme agama. Dalam pandangan Esack, ada kemungkinan untuk hidup berdampingan dalam kepercayaan penuh terhadap al-Qur'an dan konteks kehidupan sekarang yang bersama-sama kepercayaan-kepercayaan lain bekerjasama untuk membangun masyarakat yang lebih manusiawi; mengembangkan gagasan hermeneutika al-Qur'an sebagai kontribusi bagi pengembangan pluralisme agama dalam Islam; menguji cara alQur'an mendefinisikan diri (muslim) dan orang lain (non-muslim) dengan tujuan untuk menciptakan ruang bagi kebenaran dan keadilan orang lain dalam teologi pluralisme untuk pembebasan;

Dalam penelitian ini, paradigma di artikan sebagai sekumpulan keyakinan, nilai dan metodologi dalam tardisi kerja ilmiah yang dianut oleh kelompok tertentu dalam Islam. Jalaluddin Rakkmat, Dabulukan Akblak Di Atas Fiqib. Jakarta: Mizan, 2007, 3738.

${ }^{10}$ Abdul Mustaqim, Dinamika Sejarah Tafsir..., 166. 
dan menggali hubungan antara eksklusivisme keagamaan dan satu bentuk konservatisme politik (yang mendukung Apartheid) di satu sisi, dan inklusivisme keagamaan dan satu bentuk politik progresif (yang mendukung perjuangan pembebasan) di sisi lain, serta memberinya dukungan rasional yang bersifat qur'ani. ${ }^{11}$

Untuk masuk dalam diskursus ini, sufficient reason (alasan yang melandasi) dari tawaran hermeneutika al-Qur'an, kegelisahan akademik yang dilalui adalah kritik atas hermeneutika sebelumnya. Dari sini konstruksi hermeneutika yang ditawarkan Farid Esack sebagai metode penafsiran al-Qur'an akan tampak. Cara ini juga untuk memudahkan dalam setiap upaya analisis kritis terhadapnya, apakah hermeneutika yang ditawarkan Esack mampu menjawab persoalan tentang kekerasan antar umat beragama.

B. Teori Hermeneutika

1. Pengertian dan Konsep Dasar Hermeneutika

Secara etimologis, hermeneutika berasal dari bahasa Yunani "bermeneuein", yang berarti mengungkapkan pikiran seseorang dalam kata-kata. Kata kerja itu juga berarti "menerjemahkan" dan juga bertindak sebagai "penafsir". Menurut Mudjia, hermeneutika adalah upaya peralihan dari sesuatu yang gelap ke sesuatu yang terang. ${ }^{12}$ Hermeneutika juga sering didefinisikan sebagai:

a. Teori penafsiran kitab suci (theory of biblical exegesis).

b. Hermeneutika sebagai metodologi filologi umum general philological methodology).

c. Hermeneutika sebagai ilmu tentang semua pemahaman bahasa (science of all linguistic understanding).

d. Hermeneutika sebagai landasan metodologis dari ilmu-ilmu kemanusiaan (methodological foundation of Geisteswissenschaften).

e. Hermeneutika sebagai pemahaman eksistensial dan fenomenologi eksistensi (phenomenology of existence dan of existential understanding).

${ }^{11}$ Ibid, 14.

${ }^{12}$ Mudjia Raharjo, Hermeneutika Gadamerian. Malang: UIN-Malang Press, 2007, 88. 
f. Hermeneutika sebagai sistem penafsiran (system of interpretation). Hermeneutika sebagai sistem penafsiran dapat diterapkan, baik secara kolektif maupun secara personal, untuk memahami makna yang terkandung dalam mitos-mitos ataupun simbol-simbol.

Dari keenam pengertian di atas, yang paling banyak dipahami oleh banyak orang, adalah hermenentika sebagai prinsipprinsip penafsiran kitab suci (principles of biblical interpretation). Ada pembenaran yang bersifat historis terhadap pemahaman ini, karena kata hermeneutika pada era modern memang digunakan untuk mengisi kebutuhan akan panduan dalam penafsiran kitab suci. Akan tetapi, hermeneutika bukanlah isi penafsiran, melainkan metodenya. Perbedaan antara penafsiran aktual (exegesis) dan aturan-aturan, metode-metode, dan teori yang mengaturnya (hermeneutika) sudah sejak lama disadari, baik di dalam refleksi teologis maupun refleksi-refleksi non teologis.

Beberapa kajian menyebut bahwa hermeneutika adalah "proses mengubah sesuatu atau situasi ketidaktahuan menjadi tahu dan mengerti". Secara lebih luas hermeneutika didefenisikan oleh Zygmunt Bauman sebagai upaya menjelaskan dan menelusuri pesan dan pengertian dasar dari sebuah ucapan atau tulisan yang tidak jelas, kabur, remang-remang dan kontradiktif yang menimbulkan kebingungan bagi pendengar atau pembaca. ${ }^{13}$

Kajian hermeneutika sejak abad 19 (atau akhir abad 18) telah menemukan bentuknya yang baru dari wajah hermeneutika sebelumnya. Secara periodik hermeneutika dapat dibedakan dalam tiga fase; klasik, pertengahan, dan modern. Hermeneutika klasik, lebih bercorak pada bentuk interpretasi teks dan "art of interpretation". Istilah ini pertama kali muncul pada abad 17 tetapi hermeneutik dalam arti sebagai aktivitas penafsiran telah lahir jauh sebelumnya, usianya setua dengan eksegesis teks.

\footnotetext{
${ }^{13}$ Fahruddin Faiz, Hermeneutika Al-Qur'an Tema-Tema Kontroversial. Yogyakarta: Elsaq,
} 2005, 5 . 
Hermeneutika pertengahan, dimulai pada saat penafsiran terhadap Bible yang menggunakan empat level pemaknaan baik secara literal, allegoris, tropological (moral), dan eskatologis. Tetapi pada masa reformasi protestan, empat pemaknaan itu kemudian disempitkan pada eksegesis literal atau gramatical dan eksegesis studi tentang Yahudi dan Yunani.

Sedangkan hermeneutika modern, dapat dibedakan dalam beberapa fase dengan aliran-aliran yang mengikutinya. Fase awal, mulai pada abad ke-19 dengan merujuk pada tokoh Protestan ternama, Friedrich Schleiermacher (1768-1834) dan murid-muridnya termasuk Emilio Betti, dengan teori hermeneutiknya (hermeneutical theory). Fase kedua, pada abad ke20 dengan Martin Heidegger (1889-1976) sebagai tokohnya, termasuk di sini Hans George Gadamer dengan aliran filsafat hermeneutik (philosophical hemeneutic), dan terakhir adalah Jurgen Habermas, dengan hermeneutik kritiknya (critical hermeneutics). ${ }^{14}$

2. Konsep Pluralisme Agama

Secara etimologi, pluralisme agama, berasal dari dua kata, yaitu "pluralism" dan "agama". Kata "pluralisme" berasal dari bahasa Inggris, pluralism. Dari definisi di atas, maka dapat di tarik suatu pengertian bahwa "pluralisme agama" adalah fakta sosial yang selalu ada dan kondisi hidup bersama (koeksistensi) antar agama (dalam arti yang luas) yang berbeda-beda dalam satu komunitas dengan tetap mempertahankan ciri-ciri spesifik ajaran masing-masing agama.

Dengan demikian, pluralisme agama tidak hendak menyatakan bahwa semua agama adalah sama. Frans Magnis Suseno berpendapat hahwa menghormati agama orang lain tidak ada hubungannya dengan ucapan bahwa semua agama sama. Agama-agama jelas berbeda satu sama lain. Perbedaanperbedaan syari'at, menunjukkan bahwa agama tidaklah sama. Setiap agama memiliki konteks partikularitasnya sendiri sehingga tak mungkin semua agama menjadi sebangun dan sama persis.

${ }^{14}$ Edi Mulyono, dkk, Belajar Hermeneutika. Yogyakarta: Ircisod, 2012, 35. 
Yang dikehendaki dari gagasan pluralisme agama adalah adanya pengakuan secara aktif terhadap agama lain. Agama lain ada sebagaimana keberadaan agama yang dipeluk diri yang bersangkutan. Setiap agama punya hak hidup. ${ }^{15}$

Nurcholish Madjid menegaskan, pluralisme tidak saja mengisyaratkan adanya sikap bersedia mengakui hak kelompok agama lain untuk ada, melainkan juga mengandung makna kesediaan berlaku adil kepada kelompok lain itu atas dasar perdamaian dan saling menghormati. ${ }^{16}$ Allah berfirman, dalam QS. al-Mumtahanah/60:8:

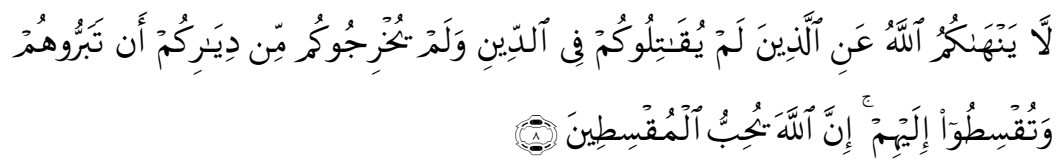

"Allah tidak melarang kamu untuk berbuat baik dan berlaku adil terhadap orang-orang yang tidak memerangi dalam urusan agama dan tidak pula mengusir kamu dari negerimu. Sesunggubnya Allab menyukai orang-orang yang berlaku adil."

Sebagaimana paparan di atas bahwa pengertian pluralisme agama adalah kemajemukan agama secara positif sekaligus optimis dengan menerimanya sebagai kenyataan (sunnatullāh) dan berupanya agar berbuat sebaik mungkin atas kenyataan tersebut.

Akan tetapi persoalannya, konsep pluralisme agama sendiri ternyata tidak bisa diterima oleh semua pihak, dan dari kenyataan ini, setidaknya para agamawan terpolarisasi dalam paradigma atau penyikapan terhadap pluralisme agama. Sebagaimana konsep pluralisme agama menurut Raimundo Panikkar, setidaknya ada tiga sikap, yaitu: pertama, sikap eklusif yaitu pandangan dan sikap yang mengklaim bahwa kebenaran dan keselamatan hanya pada agama yang dianutnya, tidak pada agama lain; kedua, inklusif yaitu pandangan dan sikap yang

${ }^{15}$ Abd. Moqsith Ghazali, Argumen Pluralisme Agama. Depok: Kata Kita: 2009, 67.

${ }^{16}$ Nurcholish Madjid, Islam, Doketrin dan Peradaban: Sebuah Telaah Kritis tentang Masalah Keimanan, Kemanusian dan Kemodernan. Jakarta: Paramadina, 1995, 602. 
mengklaim bahwa agama yang dianutnya memiliki kebenaran dan keselamatan yang lebih sempurna dibanding dengan agama lain. Artinya agama lain masih mungkin memiliki kebenaran dan keselamatan pada tataran tertentu asalkan memiliki sejumlah kriteria tertentu; ketiga, pluralis yaitu pandangan dan sikap yang mengklaim bahwa terdapat banyak jalan menuju yang Satu (kebenaran) yang menunjukkan diri-Nya dengan sangat banyak cara, sehingga setiap orang hendaknya menuruti jalannya masing-masing sebaik mungkin agar selamat, atau dengan kata lain pluralisme mengklaim bahwa semua agama mengandung kebenaran dan menuju kepada jalan yang sama. ${ }^{17}$

C. Konsep Hermeneutika dan Pluralisme Agama

1. Konsep Hermeneutika Farid Esack

Metode hermeneutik yang digunakan oleh Farid Esack dalam karyanya al-Qur'an, Liberation and Pluralism adalah menempatkan hermeneutika secara umum pada dua arus utama yakni hermeneutical theory dan bermeneutical philosophy, meskipun secara jujur, terkadang dalam beberapa waktu, Farid Esack sering berposisi di wilayah kritis mazhab Habermasian. Dengan dua pendekatan yang ia pakai, Farid Esack ingin merangkum pendekatannya dalam memposisikan dirinya secara metodologis dalam gugusan konsep hermeneutikanya, yakni bagaimana agar sebuah kata atau satu kejadian dalam waktu dan budaya lampau dapat dimengerti dan menjadi bermakna secara eksistensial dalam situasi sekarang.

Dalam konteks penindasan Afrika Selatan, penggunaan hermeneutik sebagai perangkat pembacaan atas realitas teks dan konteks Afrika Selatan menjadi satu hal penting yang tidak bisa ditawar-tawar lagi. Sehubungan dengan hal ini, ada empat hal yang ingin dituju Farid Esack berkaitan dengan penyelidikan yang ia lakukan dalam bukunya. Pertama, ingin menunjukan bahwa sangat mungkin hidup dalam keimanan terhadap al-

${ }^{17}$ Raimondo Panikkar, Dialog Intra Religious, terj. Oleh KSF Driyarkara, Yogyakarta: Kanisius, 1994, 18-24. 
Qur'an di satu sisi dan dalam satu konteks yang hadir (kontemporer) bersama umat lain, bekerjasama dengan mereka guna membangun masyarakat yang lebih manusiawi. Kedua, mengedepankan ide tentang hermeneutik al-Qur'an sebagai kontribusi terhadap bangunan teologi pluralisme dalam Islam.

Ketiga, mengkaji ulang cara al-Qur'an mengkaji diri sendiri dan orang lain (baik yang beriman atau tidak beriman) untuk memberikan ruang kebenaran bagi orang lain dalam teologi pluralisme demi pembebasan. Keempat, mencari hubungan antara eksklusivisme keagamaan dengan satu bentuk konservatisme politik (pendukung Apartheid) di satu sisi, serta inklusivisme keagamaan dengan satu bentuk politik progresif (pendukung pembebasan) di sisi lain, dan untuk memberikan alasan-alasan bagi yang terkahir. ${ }^{18}$

Jika dicermati lebih dekat, memang Esack tidak begitu rigid dan detail dalam merumuskan secara teoritis konsep hermeneutikanya, namun bila dirunut secara epistemologis, dapat diketahui dari karyanya (al-Qur'an, Liberation and Pluralism) bahwa gagasan besarnya ini ternyata bermuara pada hermeneutika tanggapan/penerimaan (reception bermeneutics) yang populer dalam tradisi Injil (Bible). Kiblat tokohnya seperti yang dia jelaskan dalam bukunya adalah rujukan hermeneutika Francis Shcussler-Fiorenza. ${ }^{19}$

Dalam kajian hermeneutika kontemporer, hermeneutika penerimaan (reception bermeneutics) biasanya selalu diidentikkan pada aliran fungsionalisme teks. Mengapa disebut demikian? Karena bagi hermeneutika ini, sebuah teks bisa dikatakan sebagai kitab suci, jika ia telah lulus "uji fungsional dan pragmatik tertentu". Dengan kata lain, aliran ini berpandangan bahwa eksistensi sebuah teks kitab suci terletak pada dimensi fungsional dan pragmatisnya, sehingga letak

\footnotetext{
${ }^{18}$ Farid Esack, Qur'an, Liberation \& Pluralism: An Islamic Perspective of Interreligious Solidarity against Oppression. Oxford: Oneworld Publications, 1997, 14.

${ }^{19}$ Ibid, 52.
} 
kebenaran tertinggi sebuah teks kitab suci dilihat dari seberapa jauh mampu mengatasi problem kemanusiaan yang hadir.

Hermeneutika penerimaan berfokus pada proses interpretasi dan bagaimana individu atau kelompok yang berbeda menggunakannya. Menurut Esack yang mengutip dari Francis Shcussler-Fiorenza, interpretasi seperti ini: "Perlu memperhatikan bukan hanya teks atau audiens awal teks itu, melainkan juga transformasi jangkauan pemahaman masa lalu dan sekarang". Hermeneutika penerimaan dengan demikian mengubah analisis soal bagaimana suatu teks telah atau sedang diterima "menjadi studi tentang teks tersebut". Proses tafsir ini tentu berlawanan dengan positivisme histories yang cenderung memperhatikan makna-makna yang tetap dan pasti (tekstual).

Hermeneutika penerimaan menuntut agar beragam penerimaan atas teks itu, termasuk pemahaman yang popular saat itu sebagai konkretisasi pemaknaannya, dilibatkan dalam masalah penafsiran teks tersebut. Dengan demikian, menurut Fiorenza, hermeneutika penerimaan akan memasukkan ke dalam usaha interpretasi masalah pergeseran jangkauan pemahaman beragam audiensnya dan tansformasi antara harapan masa lalu dan sekarang terhadapnya. ${ }^{20}$

Untuk memperlihatkan bagaimana hermeneutika alQur'an bekerja, dengan dialektika tanpa henti antara teks dan konteks serta pengaruhnya terhadap satu sama lain. Kontruksi hermeneutika al-Qur'an Farid Esack,mempunyai karakteristik yaitu bersifat spesifik dan temporal. Sebagai penafsiran yang berorientasi sosial, dengan metode hermeneutika untuk mengkontruksi konsep pluralisme agama bagi masyarakat Afrika Selatan. Pemikiran hermeneutika al-Qur'an Farid Esack terinspirasi dari konsep teologi pembebasan (liberation theology) Gueterriez dan Segundo, hermeneutika lingkar

${ }^{20}$ Ahmala Arifin, Tafsir Pembebasan: Metode Interpretasi Progresif Ala Farid Esack. Yogyakarta: Aura Pustaka, 2011, 47. 
bahasa, metode hermeneutik "regresif-progresif" Arkoun dan hermeneutika "double movement" Fazlur Rahman.

Farid Esack mengadopsi secara kreatif dan kritis tiga pemikiran tersebut serta melengkapinya dengan term-term hermeneutika al-Qur'an yang memiliki koherensi dan korespondensi dengan kondisi sosial masyarakat Afrika Selatan. Saat itu, Afrika Selatan diliputi oleh penindasan, ketidakadilan dan eksploitasi. Farid Esack dengan term-term hermeneutika alQur'annya koherensi dan korespondensi dengan kondisi sosial masyarakat Afrika Selatan, yaitu sebuah kondisi yang diliputi oleh penindasan, ketidakadilan dan eksploitasi. Term-term tersebut adalah kata-kata kunci yang diambil dari al-Qur'an seperti: taqwa (integritas dan kesadaran akan kehadiran Tuhan), tawhìd (ke-Esa-an Tuhan),al-nās (manusia), almustad'afün (yang tertindas), qist dan 'adl (keseimbangan dan keadilan), serta Jiha ${ }^{-} d$ (perjuangan dan praksis). ${ }^{21}$

Hermeneutika al-Qur'an di dalam situasi ketidakadilan berarti menjalani teologi dan mengalami iman sebagai solidaritas dengan kaum tertindas dan tersisih dalam perjuangan pembebasan. Cara kerja term-term di atas ada kaitan antara jalan Tuhan mengidentikan diri dengan kemanusiaan (al-nās); hubungan antara jalan Tuhan dan jalan kemanusiaan: pilihanNya atas manusia tertindas dan marginal serta pentingnya menegakkan keadilan (qisth dan 'adl) atas dasar tawbid dan taqwā melalui jibàd.

2. Konsep Pluralisme Agama Farid Esack

Menurut Farid Esack, al-Qur'an sebenarnya secara tegas dan jelas menunjukkan adanya pluralitas dan keanekaragaman agama. ${ }^{22}$

${ }^{21}$ Ibid, 83

${ }^{22}$ Farid Esack, Qur'an, Liberation \& Pluralism: An Islamic Perspective of Interreligious Solidarity against Oppression. Oxford: Oneworld Publications,1997, 83, 86-87. 


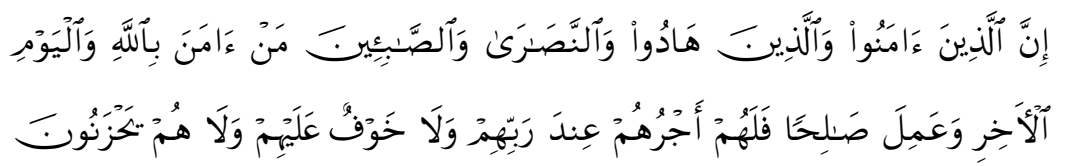

"Sungguh, orang-orang yang beriman, Yahudi, Sabi'in, Nasrani, dan siapa saja di antara mereka yang beriman kepada Allah, Hari Akhir, dan berbuat kebajikan, mereka akan mendapatkan balasan dari sisi Tuhan mereka, tidak ada kekhawatiran pada mereka dan tidak pula mereka akan bersedih hati”. (QS. al-Baqarah/2: 62).

Ayat tersebut, menurut Esack, secara tegas menyatakan adanya keselamatan yang dijanjikan Tuhan bagi setiap orang yang beriman kepada-Nya dan Hari akhir, yang diiringi dengan berbuat kebajikan (amal saleh) tanpa memandang afiliasi agama formal mereka.

Pandangan Farid Esack terhadap pluralisme agama dalam al-Qur'an merupakan manifestasi perjuangannya, bagi masyarakat Afrika Selatan tanpa memandang asal-usul agama, yang tujuan akhirnya adalah terwujudnya tatanan sistem politik yang demokratis dan menghargai pluralitas agama. ${ }^{23}$ Oleh karena itu Farid Esack menggunakan kunci-kunci hermeneutika sebagai tolok ukur agar sebuah penafsiran tidak terjerumus ke dalam subyektivitas penafsiran, tanpa meninggalkan kaidah-kaidah penafsiran para mufassir terdahulu.

Hermeneutika al-Qur'an tentang pluralisme agama sebagai temuan penelitian Farid Esack merupakan rumusan perspektif baru dalam hubungan antaragama dan peletakan dasar bagi sikap kritis terhadap penganut agama yang sama. Dengan perspektif baru ini, Farid Esack berupanya mendobrak klaim kebenaran eksklusif suatu agama.

Dalam memformulasi konsep pluralisme agama untuk masyarakat Afrika Selatan, dengan metode hermeneutika untuk melakukan pembacaan kembali (reinterpretasi) terhadap

${ }^{23}$ Farid Esack, Qur'an Liberation \& Pluralism..., 123. 
sejumlah konsepsi keagamaan imān, isläm, kufr, dan penggambaran kaum lain: abl al-kitāb dan musyrike. ${ }^{24}$ Sebagaimana yang dipahami dalam format tradisi pemikiran Islam klasik dalam konteks Afrika Selatan, keberadaan konsepsi-konsepsi tersebut selain berperan sebagai penyangga dimensi transendensi-spiritualitas umat, juga mempunyai pengaruh yang sangat signifikan dalam konteks kehidupan sosial-politik.

a. Iman

Untuk mendapatkan pemahaman imān yang lebih inklusif Farid Esack secara filosofis mendasarkan pandanganya pada keterangan al-Qur'an dalam QS.al-Anfal/8: 2-4:

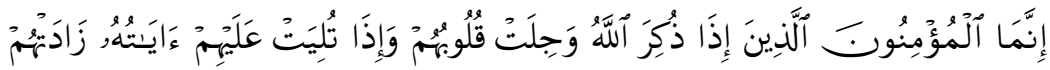

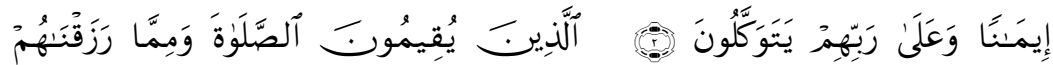

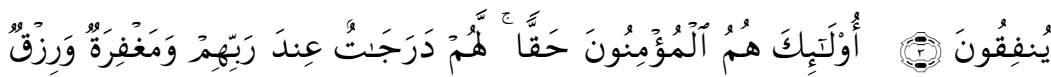

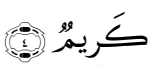

"Sesunggubnya orang-orang yang beriman ialah mereka yang bila disebut nama Allah gemetarlah hati mereka, dan apabila dibacakan ayat-ayatNya bertambablab iman mereka (karenanya), dan hanya kepada Tuhanlah mereka bertawakkal. (yaitu) orang-orang yang mendirikan shalat dan yang menafkabkan sebagian dari rezeki yang Kami berikan kepada mereka. Itulah orang-orang yang beriman dengan sebenarbenarnya. Mereka akan memperoleh beberapa derajat ketinggian di sisi Tuhannya dan ampunan serta rezeki (nikmat) yang mulia." (QS. alAnfal/8: 2-4).

Dalam pandangan Farid Esack, dari sekian ayat al-Qur'an yang menjabarkan tentang kata $\bar{i} m \bar{m}$, hanya ayat di atas yang paling jelas dan utuh dalam mendefinisikan kata-kata mu'min. Namun demikian, dalam kaitan ini Farid Esack tidak berusaha merumuskan konsep dasar keimanan (teologi) umat Islam dalam

${ }^{24}$ Farid Esack, Qur'an Liberation \& Pluralism..., 117. 
bentuk yang baru, melainkan mencoba menyelidiki status ontologism dan aksiologis dari konsep imän dan mu'min dalam ruang yang lebih terbuka. Farid Esack mencoba menggali hakikat konsep iman dengan menguraikan tiga inti persoalan yang saling terkait, yang terkandung pada ayat di atas. Pertama, menjelaskan watak dinamis iman, kedua, merefleksikan keterhubungan antara iman dan amal saleh, ketiga, menegaskan konsep imān sebagai respons personal terhadap Tuhan.

b. Islam

Makna Isläm dalam wacana kaum Muslim pada umumnya diartikan sebagai ekspresi keagamaan yang dapat diterima Tuhan sejak kenabian Muhammad, dan sebagai sebuah nama bagi agama yang dibawa Nabi Muhammad. Pengertian ini didasarkan pada ayat berikut:

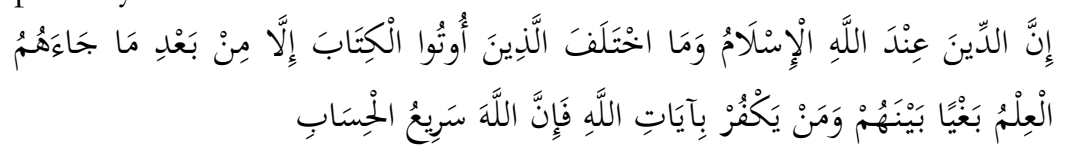

"Sesungguhnya agama (yang diridhai) disisi Allah hanyalah Islam, tiada berselisih orang-orang yang telah diberi Al-Kitab kecuali sesudah datang pengetahuan kepada mereka, karena kedengkian (yang ada) di antara mereka. Barangsiapa yang kafir terhadap ayat-ayat Allah maka sesungguhnya Allah sangat cepat hisab-Nya." (QS. Ali Imran/3:19).

Dalam konteks ini Farid Esack tidak menafsirkan Isläm sebagai $\overline{d i n}$, melainkan lebih menekankan pada sebuah proses term din dipahami sebagai penyerahan diri kepada Tuhan. Ada beberapa argumen menurut Farid Esack yang bisa dijadikan sebagai alasan mengapa din tidak harus diartikan sebagai agama formal. Pertama, selama abad ke tujuh, di jazirah Arab, term din dipergunakan untuk makna yang beraneka ragam. Dalam konteks ini, al-Qur'an tidak bisa menghindar untuk menggunakan batasan-batasan makna yang telah ada. Tidak ditemukannya bentuk jamak din dalam al-Qur'an, yakni adyān, barangkali mengisyaratkan bahwa kehidupan keberagamaan saat 
itu memang tidak sepenuhnya dilembagakan. Kedua, al-Qur'an menggunakan term din untuk memudahkan kepada pembaca dalam memahaminya. Karenanya, istilah din tidak dipergunakan dalam pengertian komunal seperti pada konteks Mekkah awal.

Ketiga, sikap menolak atau menerima terhadap din atau yawm al-din tidak ada sangkut pautnya dengan penegasan atau penyangkalan secara verbal atau teoritis, melainkan terkait dengan sikap atau perilaku pribadi yang memberi respons terhadap Tuhan serta suatu panggilan moral yang lebih tinggi atau sebaliknya. Keempat, pengertian yang universal terhadap makna din sebagai agama, dengan mengganti pengertiannya sebagai respons terhadap Tuhan, jelas tidak mempunyai dasar baik di dalam teks al-Qur'an atau pada tafsir-tafsir tradisional. ${ }^{25}$

Berpijak dari keterangan-keterangan yang sangat logis dan mendasar tadi, dan tentunya dipadukan dengan konteks Afrika Selatan sebagai lokus pengalaman hermeneutiknya, Farid Esack mencoba merangkum pemaknaan Isläm ke dalam dua pengertian; 1) menunjukan pentingnya ketundukan pribadi dalam kerangka identifikasi kelompok, 2) memberikan kemungkinan ketundukan pribadi di luar parameter historis komunitas Islam .

c. Kufr

Berbicara tentang masalah kufr, Farid Esack menyandarkan pandangannya pada Firman Allah yang berbunyi:

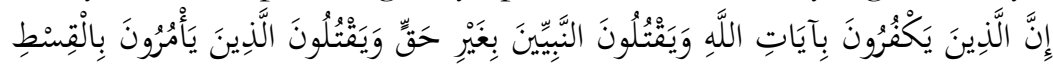

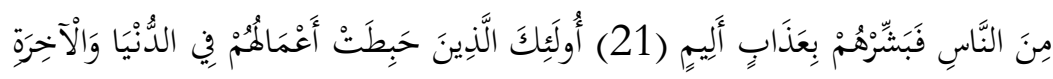
وَمَا لَهْْْ مِنْ نَاصِرِينَ (22)

"Sesunggubnya orang-orang yang kafir kepada ayat-ayat Allab dan membunuh para nabi yang memang tak dibenarkan dan membunuh orang-orang yang menyuruh manusia berbuat adil, maka gembirakanlah mereka babwa mereka akan menerima siksa yg pedih. Mereka itu adalah

${ }^{25} \mathrm{Ibid}, 128$. 
orang-orang yang lenyap (pahala) amal-amalnya di dunia dan akbirat, dan mereka sekali-kali tidak memperoleb penolong." (QS. Āli 'Imrān/3: 21-22).

Menurut Farid Esack, ayat ini menggabungkan unsur doktrinal (kufr) dan sosio-politik (keadilan). Kalangan Islamis konservatif dianggap telah gagal membedakan kufr sebagai perilakan aktif individu (sekelompok individu) dan sebagai idetitas sosio-religius (dan juga etnis) suatu kelompok. Yang relevan di sini adalah kata bentuknya, (käair), telah merasuk ke dalam wacana rasialis Afrika Selatan sebagai ekspresi paling menghina bagi mayoritas kulit hitam yang dianggap tidak menampakkan tanda-tanda keyakinan atau kepercayaan pada mereka. ${ }^{26}$

Ketika meninjau sisi doktrinal kufr di dalam al-Qur'an, ada beberapa hal penting yang mesti diperhatikan agar dapat menghindari perlakuan tidak adil terhadap mereka yang tidak berlabel "Muslim". Pertama, ketika al-Qur'an mengaitkan kufr dengan doktrin, itu dilakukan dalam konteks sosio-histroris riil dan yakin bahwa kepercayaan yang tulus kepada ke-Esa-an Tuhan dan pertanggungjawaban akhir kepada-Nya akan membawa terwujudnya masyarakat yang adil. Dengan argument bahwa ada keterkaitan intrinsik antara kepercayaan dengan konsekuensi memegang kepercayaan itu, seseorang tidak bisa membicarakan kufr secara doktrinal murni tanpa mengaitkannya dengan realitas sosial. Menyangkal Tuhan misalnya, selalu terkait dengan pelanggaran janji dan menyebarkan korupsi (QS. alBaqarah/2: 28). tanpa mengaitkan sisi doktrinal kufr dengan yang ahistoris, tidak mencerminkan adanya hubungan dialektis antara wahyu dan masyarakat. ${ }^{27}$

Kedua, al-Qur'an menggambarkan käfir (si pelaku) sebagai sosok yang mengetahui ke-Esaan Tuhan dan Muhammad sebagai utusan-Nya. Namun memilih menolak untuk

${ }^{26}$ Ahmala Arifin, Tafsir Pembebasan...,.97.

${ }^{27}$ Farid Esack, Qur'an Liberation \& Pluralism..., 136. 
mengakuinya. Makna linguistik kufr sebagai "menutupi sesuatu", konsisten di sepanjang isi al-Qur'an ketika persoalan yang tampaknya bersifat doktrinal diangkat dan al-Qur'an berulangkali mencela kufr-nya tindakan menyembunyikan kebenaran.

Ketiga, yang dicela al-Qur'an sebagai kufr adalah sikap permusuhan terhadap Islam dan Muslim, dalam pengertian tunduk kepada Tuhan dan orang-orang yang hendak mengorganisasikan keberadaan kolektif mereka atas dasar ketundukan itu. Keempat, al-Qur'an juga bersifat spesifik mengenai keputusan kufr untuk menolak keyakinan tertentu. Di sini harus dipahami bahwa keyakinan berimplikasi lebih dari sekedar pergeseran mental dari suatu ide ke ide lainnya, tetapi lebih jauh dari itu, menurut perubahan radikal atas hidup seseorang, nilai-nilai dan hubungan sosio-ekonomi. ${ }^{28}$

d. Ahl al-kitab

Dalam konteks penindasan Afnka Selatan, memperluas cakupan Abl al-Kitāb dengan menetapkan kesamaan dalam wilayah praktik dan perilaku merupakan pilihan yang tepat. Selain karena tidak adanya batasan yang jelas kelompok mana saja yang bisa digolongkan sebagai Abl al-Kitāb, bentuk pengakuan serta kebutuhan yang mendasar terhadap rasa solidaritas antar sesama kaum tertindas dalam masyarakat eksploitatif dan tidak adil, lebih di utamakan.

Oleh karenanya, dalam pandangan Farid Esack label $A b l$ al-Kitāb merupakan term religius yang sifatnya situasional. Dalam artian, ke dalam term ini bisa dimasukan beberapa kelompok keagamaan yang memiliki kategori-kategori spesifik sesuai dengan pertimbangan konteks geopolitik dan kecenderungan si penafsir. Sehingga tak aneh jika kemudian terjadi polemik di kalangan mufasir apakah kelompok keagamaan seperti Hindu, Budha, Zoroaster, Pagan termasuk ahl al-Kitāb atau bukan?

${ }^{28} \mathrm{Ibid}, 137$. 
Menjawab rentetan persoalan seperti ini dalam konteks zaman modern sekarang ini bagi Farid Esack menjadi kurang urgen dan relevan lagi. Sebab yang menjadi permasalahan utama sekarang ini adalah apa relevansi dari keberadaan kelompok ini bagi perjuangan rakyat Afrika Selatan khususnya. Yang terpenting untuk konteks saat ini, adalah bagaimana meruntuhkan segala bentuk hegemoni dan dominasi khususnya dalam bidang teknologi dan politik di dunia yang notabene dipegang oleh dua kekuatan besar; Kristen dan Yahudi. ${ }^{29}$ Lewat pembacaan hermeneutika al-Qur'an tentang solidaritas antar agama ini Farid Esack mencoba menawarkan sebuah pembacaan yang lebih inklusif terhadap kedua kelompok ini dengan merangkul kaum tertindas sebagai kelompok par excellent dari term ini.

e. Musyrik

Tidak diragukan lagi bahwa dalam tahap perkembangan Islam awal, istilah musyrik dipergunakan untuk menyebut sekelompok warga Mekkah yang menyembah objek-objek fisik, seperti patung atau benda-benda keramat sebagai entitas yang sakral, tetapi kemudian juga diterapkan bagi $A b l$ al-Kitāb oleh sebagian ahli fiqih. ${ }^{30}$

Namun dalam pembacaan Farid Esack, pemaknaan musyrik seperti di atas tidak bisa diterima sebagai satu-satunya makna baku sebagaimana makna awalnya. Hal ini didasarkan pada dua alasan. Pertama, di satu sisi syirk digunakan al-Qur'an guna mernyebut Abl al-Kitāb (misalnya QS. al-Taubah/9:31), namun pada saat yang bersamaan al-Qur'an juga membedakannya secara tegas dengan kaum musyrik. Kedua, melihat perkembangan hubungan kaum muslim dengan dunia non-Muslim yang semakin luas. ${ }^{31}$

\footnotetext{
${ }^{29}$ Ibid, 153.

${ }^{30}$ M. Quraish Shihab, Wawasan Al-Qur'an: Tafsir Tematik Atas Pelbagai Persoalan Umat. Bandung: Mizan, 2013, 472.

${ }^{31}$ Farid Esack, Qur'an Liberation \& Pluralism..., 154.
} 
Menyikapi terpilah-pilahnya fakta-fakta al-Qur'an yang menyinggung masalah ini, ditambah lagi dengan semakin kompleksnya persoalan religio-sosio-politis di dunia kontemporer, membuat Farid Esack sangat berhati-hati untuk menerapkan kategori-kategori syirk secara sempit dan kaku terhadap kelompok di luar Islam, sebagaimana yang diterapkan oleh kebanyakan mufasir klasik. Sehubungan dengan hal ini, pemikiran hermeneutik Farid Esack mencoba menggali sebuah pemaknaan baru yang dianggap mampu melintasi konteks pembacaan masa lalu. Namun yang menjadi kehatian-hatian utama Farid Esack, tampaknya secara fundamental lebih didasarkan pada analisa objektif terhadap fenomena sosialkeagamaan yang secara ekstensif muncul di beberapa negara. Hal ini terlihat dari data-data yang disodorkan Farid Esack sebagai pijakan utamanya.

Pertama, munculnya fenomena gerakan keagamaan di beberapa negara seperti di India, yang banyak mencampuradukan dimensi religiousitas, semisal orang mengaku Kristen dan pagan, Budha dan Hindu-Katolik sekaligus. Kedua, ada orang di sebagian besar wilayah Asia, Australia, Amerika Latin dan Afrika yang menggabungkan komitmen pada Islam, Kristen dan bahkan Yudaisme sekaligus dengan praktik pagan tradisional, seperti penghormatan pada makam kramat, jimat, dan benda-benda pusaka untuk memohon rahmat dan kekayaan dari nenek moyangnya. Ketiga, terdapat penggunaan secara sistematis agama formal dan institusional di wilayah-wilayah itu untuk menindas, mengeksploitasi, bahkan menghapuskan masyarakat pribumi. Akibatnya, dalam kondisi seperti ini banyak penganut agama yang menyandarkan pertolongannya kepada nenek moyang mereka sebagai jalan untuk menegaskan martabat kemanusiaan mereka. ${ }^{32}$

${ }^{32}$ Farid Esack, Qur'an Liberation \& Pluralism...,154-155. 
Dalam pandangan Farid Esack term syrik, bisa dikatakan merupakan antitesis dari tawhi $d$. Ia mempunyai implikasi praksis terhadap munculnya kesenjangan sosio-ekonomi yang begitu lebar pada masyarakat Mekkah. Sehingga teks-teks awal alQur'an yang menyinggung masalah tersebut, sejatinya merupakan reaksi keras terhadap pemujaan warga Mekkah pada berhala di satu sisi dan melanggengkan sistem hegemoni sosial dalam bentuk ketidakadilan dalam masalah ekonomi di sisi lainnya. ${ }^{33}$ Dengan demikian, penyebutan syirk atau musyrik dalam al-Qur'an selain terkait dengan masalah keyakinan, juga memiliki keterkaitan erat dengan munculnya ketimpangan sosial.

\section{Kesimpulan}

1. Metode hermeneutik yang digunakan oleh Farid Esack dalam karyanya al-Qur'an, Liberation and Pluralism adalah menempatkan hermeneutika secara umum pada dua arus utama yakni hermeneutical theory dan hermeneutical philosophy, bahwa gagasan besarnya ini ternyata bermuara pada hermeneutika tanggapan/penerimaan (reception bermeneutics) yang populer dalam tradisi Injil (Bible). Hermeneutika penerimaan (reception bermeneutics) biasanya selalu diidentikkan pada aliran fungsionalisme teks. Dimana, aliran ini berpandangan bahwa eksistensi sebuah teks kitab suci terletak pada dimensi fungsional dan pragmatisnya, sehingga letak kebenaran tertinggi sebuah teks kitab suci dilihat dari seberapa jauh mampu mengatasi problem kemanusiaan yang hadir.

2. Hermeneutika al-Qur'an tentang pluralisme agama sebagai temuan penelitian Farid Esack merupakan rumusan perspektif baru dalam hubungan antara-gama dan peletakan dasar bagi sikap kritis terhadap penganut agama yang sama. Dengan perspektif baru ini, Farid Esack berupaya mendobrak klaim kebenaran eksklusif suatu agama.

${ }^{33}$ Ibid,.155. 
Dalam memformulasikan konsep pluralisme agama untuk masyarakat Afrika Selatan, Esack menggunakan metode hermeneutika untuk melakukan pembacaan kembali (reinterpretasi) terhadap sejumlah konsepsi keagamaan imān, islam, kufr, dan penggambaran kaum lain: abl al-kitāa dan musyrik. Konsep pluralisme agama yang ditawarkan Farid Esack didasarkan atas kepentingan sosiologis dan teologis. Secara sosiologis, kondisi masyarakat Afrika Selatan membutuhkan kerja sama untuk menegakkan keadilan dan kebenaran, sedang secara teologis didasarkan atas penafsirannya terhadap teks alQur'an. Menurutnya, al-Qur'an secara eksplisit dan implisit menghargai dan menerima kebenaran pada agama lain, sehingga kerja sama muslim-non muslim harus dilakukan atas dasar kesadaran teologis ini. 
Spiritualis, vol. 6, no. 1, Maret 2020| 24

\section{DAFTAR PUSTAKA}

Arifin, Ahmala. Tafsir Pembebasan: Metode Interpretasi Progesif Ala Farid Esack. Yogyakarta: Aura Pustaka, 2011.

Bakker, Anton dan Achmad Charis Zubair. Metodologi Penelitian Filsafat. Yogyakarta: Kanisius, 1990

Bleicher, Josef. Hermenentika Kontemporer, Hermeneutika sebagai Metode Filsafat dan Kritik. terj.:Imam Khoiri, Yogyakarta: Fajar Pustaka, 2007.

Departemen Agama RI. Al-Qur'an Tafsir Perkata. Jakarta: Kalim, 2010.

Esack, Farid. Membebaskan Yang Tertindas, Qur'an, Liberalisme, Pluralisme. terj. Watung A. Budiman, Bandung: Mizan, 2000.

Esack, Farid. Qur'an, Liberation \& Pluralism: An Islamic Perspective of Interrelegious Solidarity against Oppression, Oxford: Oneworld Publications,1997.

Esack, Farid. Contemporary Religious Thought in South Africa and the Emergence of Qur'anic Hermeneutical Notions", dalam ICMR, vol. 2, no.2 1991 .

The Qur'an; a Users Guide, Oxford: OneWorld Publication, 2005.

. On Being a Muslim; Fajar Baru Spiritualisme Islam LiberalPlural, Yogyakarta: IRCISOD, 2005.

Faiz, Fakhruddin. Hermeneutika Al-Qur'an: Tema-tema Kontroversial. Yogyakarta:Elsaq Press, 2005.

Hidayat, Komaruddin. Menafsirkan Kehendak Tuhan. Jakarta: Teraju, 2004.

Madjid, Nurcholish. Islam, Doktrin dan Peradaban: Sebuah Telaab Kritis tentang Masalah Keimanan, Kemanusian dan Kemodernan. Jakarta: Paramadina, 1995.

Mannā' Khalil al-Qattān, Mababits fi Ulumil Qur'an. Kairo: Maktabah Wahbah, 2000.

Misrawi, Zuhairi. Al-Qur'an Kitab Toleransi. Jakarta: Pustaka Oasis, 2010. Mulyono, Edi dkk. Belajar Hermeneutika. Yogyakarta: Ircisod, 2012. 
Mustaqim, Abdul dan Sahiron Syamsudin. Studi Al-Qur'an Komtemporer; Wacana Baru Berbagai Metodologi Tafsir. Yogyakarta: Tiara Wacana, 2002.

Mustaqim, Abdul. Dinamika Sejarah Tafsir al-Qur'an: Studi Aliran-aliran Tafsir dari Periode Klasik hingga Modern-Kontemporer. Yogyakarta: Adab Press, 2012.

Panikkar, Raimondo. Dialog Intra Religious, terj. Oleh KSF Driyarkara, Yogyakarta: Kanisius, 1994.

Raharjo, Mudjia. Hermeneutika Gadamerian. Malang : UIN-Malang Press, 2007.

Rakkmat, Jalaluddin. Dabulukan Akblak Di Atas Fiqib. Jakarta: Mizan, 2007.

Shihab, M. Quraish. Tafsir al-Misbah: Pesan, Kesan dan Keserasian al-Qur'an. Volume I, Jakarta: Lentera Hati, 2000.

Shihab, M. Quraish. Wawasan Al-Qur'an: Tafsir Tematik Atas Pelbagai Persoalan Umat. Jakarta: Lentera Hati, 2013. 